\title{
冷間プレス成形角形鋼管柱の局部座屈による耐力劣化挙動の解析モデル NUMERICAL MODEL FOR DETERIORATION BEHAVIOR CAUSED BY LOCAL BUCKLING OF COLD PRESS-FORMED SQUARE HOLLOW SECTION COLUMNS
}

\author{
谷口耕一年, 聲高裕治*2, 陳 逸鴻 ${ }^{* 3}$, 田中昂平*4 \\ Koichi TANIGUCHI, Yuji KOETAKA, Iathong CHAN \\ and Kohei TANAKA
}

\begin{abstract}
In order to simulate deterioration behavior of cold press-formed square hollow section (SHS) columns, procedure to build up numerical model, called as multi-spring model, is proposed in this paper. Following regulations are considered for modeling; differences of material properties between flat area and corner area, hysteresis curve after local buckling, and transformation of plastic deformation considering with equivalence of plastic dissipation energy in the entire either plastic region or local buckling region. From comparison between multi-spring model and either finite element model or experiment, it is clarified that the proposed model is valid for simulating deterioration behavior of SHS columns.
\end{abstract}

Keywords : Cold press-formed SHS column, Local buckling, Hysteresis characteristics, Multi-spring model, Finite element analysis 冷間プレス成形角形鋼管柱, 局部座屈, 復元力特性, マルチスプリングモデル，有限要素法解析

\section{1. 序}

巨大地震を受ける鋼構造骨組では，部材の座屈や接合部の破断を 伴って抵抗力が低下 (以下，耐力劣化）し，最悪の場合には倒壊に至 る可能性のあることが，過去の地震被害 ${ }^{1)}{ }^{2)}$ や震動台実験 ${ }^{3)}$, 4) によっ て指摘されている。このような鋼構造骨組の倒壊挙動に及ぼす諸因 子の影響を数值解析によって検討するためには, 座屈や破断に伴う 耐力劣化域の復元力特性を考慮する必要がある．鋼構造骨組に多く 用いられる冷間成形角形鋼管柱に対象を絞ると，耐力劣化域の復元 力特性を再現する数值解析モデルとして, (1) 3 次元有限要素モデル, (2) 1 次元有限要素モデル(ファイバーモデル)，(3) マルチスプリング モデル，(4) 降伏線理論モデル，(5)一般化塑性ヒンジモデル，(6) 単純 塑性ヒンジ(単軸回転ばね)モデルが, 既往の研究で提案されている.

このうち(1) 3 次元有限要素モデルについては, 倉田ら ${ }^{5)}$, 井根ら ${ }^{6)}$, 奥ら ${ }^{7)}$ によっ, 局部座屈による耐力劣化を考慮した解析が行われ ている。また齋藤ら ${ }^{8}$ は，要素の損傷指標が一定值に達したものを 削除することで, 局部座屈だけでなく延性破断も考慮した解析を行っ ている. 3 次元有限要素モデルは，引張試験等に基づく材料そのもの の応力一歪関係を用い，かつ硬化則等を調整することで，実験で確認 された耐力劣化域の力学的挙動 (以下, 耐力劣化挙動) を概将再現す ることができるが，後述する他のモデルと比べて計算負荷が大きい.

一方, 山田ら ${ }^{9)}$, Suzuki ら ${ }^{10)}$ は, (2) 1 次元有限要素モデルによっ て局部座屈を考慮した解析を行っている. 1 次元有限要素モデルでは, 材料そのものの応力一歪関係を用いることが一般的であるが，これら
の研究では圧縮側の応力ー歪関係に局部座屈発生後の応力劣化を導入 している. また, 曲げモーメント勾配を有する部材に 1 次元有限要 素モデルを適用する場合，材軸方向の要素分割によって最大耐力到 達までの塑性化領域の拡がりや局部座屈領域での変形の進展が異な るため, 材軸方向の要素分割に配慮が必要となる。これに対して安 井 ${ }^{11)}$ は，応力一歪関係には局部座屈の影響を考慮せず，その代わりに 局部座屈領域内の角形鋼管柱を周方向に分割して一般化塑性ヒンジ を有する棒材に置換することで，局部座屈による耐力劣化を表現し ている.

他方, 石田ら ${ }^{12), 13)}$ は, 短柱圧縮試験に基づく復元力特性を適用し た(3)マルチスプリングモデル(以下，MS モデル)を用いて, 冷間ロー ル成形角形鋼管柱の局部座屈による耐力劣化挙動を追跡している. $\mathrm{MS}$ モデルは計算負荷が小さく, 初期降伏以降の弾塑性挙動や耐力劣 化域の挙動を容易に扱うことができる.

塑性理論に基づく解析モデルとして，松井ら ${ }^{14)}$ は(4)降伏線理論モ デルを用いることで，宮林ら ${ }^{15)}$ は(5)一般化塑性ヒンジモデルに多重 降伏曲面を取り入れ, さらに最大耐力到達後に降伏曲面を内側に移 動および収縮させることで，それぞれ局部座屈による耐力劣化域の 復元力特性の再現を試夕ている。.また, 加藤・秋山ら ${ }^{16)}$ は, (6)単純 塑性ヒンジモデルの耐力劣化域の復元力特性を提案している. (4) 降 伏線理論モデル, (5) 一般化塑性ヒンジモデル, (6) 単純塑性ヒンジ モデルは計算負荷が極めて小さいが，断面内での塑性化の進展状況 や損傷の差異を区別できない。さらに，(6)単純塑性ヒンジモデルは
*1 日建設計 修士 (工学) (元·京都大学大学院生)

*2 京都大学大学院工学研究科建築学専攻 准教授. 博士 (工学)

*3 長崎大学大学院工学研究科総合工学専攻 助教·博士 (工学)

*4 京都大学大学院工学研究科建築学専攻 大学院生
Nikken Sekkei LTD, MEng. (Former Grad. Student of Kyoto Univ.)

Assoc. Prof., Dept. of Architecture and Architectural Engineering, Kyoto Univ., Dr.Eng. Assist. Prof., Dept. of Advanced Engineering, Nagasaki Univ., Dr.Eng.

Grad. Student, Dept. of Architecture and Architectural Engineering, Kyoto Univ. 
変動軸力の影響を考慮することができない.

以上で述べた各解析モデルの特徵を踏まえ，著者等の一部が開発 を進めている任意方向の地震動を受ける鋼構造立体骨組の倒壊挙動 を追跡可能な数值解析プログラム ${ }^{17)}$ への適用を鑑みて, 本一連の研 究では解析精度の確保と計算負荷の抑制の両立が可能なモデルとし て MS モデルを用いることとした ${ }^{18)}$. 本論では, 鋼構造骨組に多く 用いられている角形鋼管柱に着目し，石田らが対象とした冷間ロー ル成形角形鋼管 ${ }^{12)},{ }^{13)}$ とは異なり, 冷間プレス成形角形鋼管を対象と した MS モデルを新たに提案する.これは, 文献 12)の解析モデル では，冷間プレス成形角形鋼管柱の局部座屈発生に伴う最大曲げ而 力の到達時期や耐力劣化域の復元力特性が精度よく追跡できないこ と ${ }^{18)}$ に基づいている.

本論の構成として, まず 2 章では, MS モデルの概要と石田らが 提案した MS モデル ${ }^{12)}$, 13) との相違点を説明する.つぎに 3 章では, 局部座屈発生後の耐力劣化挙動を把握するために有限要素法解析を 行い, MS モデルの復元力特性を定めるために必要となる局部座屈領 域内における応力一歪関係を定式化する. 4 章では, 3 章で定式化し た応力-歪関係に基づいて MS モデルの構築方法を詳述し，5 章では MS モデルの妥当性を確認するために, 耐力劣化域の復元力特性を有 限要素法解析結果や実験結果と比較する.

\section{2. 解析モデルの概要}

2.1 マルチスプリングモデル（MS モデル）

MS モデルは, 図 1 に示すように, 部材中間の弾性要素と部材端 の MS 要素によって構成される. 弾性要素は, 元の部材と同じ断面 諸量と長さを有しており, 軸方向変形, 曲げ変形, せん断変形の弾 性成分を考慮するものである. MS 要素は, 柱断面を複数の領域に分 割し, 各領域の図心に軸方向変形だけを生じる軸ばねを配置するこ とによって, 柱断面の軸力と曲げモーメントに対する弾塑性挙動を 表現するものである。軸ばねは, 図 2 に示すように分割された領域 と一致する断面積 $A$ と, 仮想長さ $L_{M S}$ （すべての軸ばねで同一）を有 するものとする. したがって, 軸ばねの軸力一軸方向変形関係 (以下, $f-d$ 関係) のうち, 弾性剛性 $k_{0}$ は鋼材のヤング係数 $E$ を用いて (1) 式 で表される.

$$
k_{0}=E \cdot A / L_{M S}
$$

ただし, 弾性要素と MS 要素の直列結合で表される MS モデル全体 の弾性剛性を, 元の部材と一致させるためには, (1) 式の弾性剛性に よって MS 要素に生じる弾性変形を除去する必要がある。この点を 含めて, MS モデルの解析方法は文献 17) に詳述している.

また, MS 要素の断面分割数は, 解析精度の確保と計算負荷の低減 との両立が図れるように決定する必要がある。本論では文献 18)の 検討に基づいて, 図 2 に示すように平板部を 4 つの要素に等分し,
角部を $1 つ の$ 要素とした断面分割 (20 分割)を採用する.

\section{2 軸ばねの軸力ー軸方向変形関係の概要}

2.1 節で述べた軸ばねの $f-d$ 関係は, 部材端における平均応力に軸 ばねの断面積 $A$ を乗じて軸力 $f$ を求め, 塑性化領域または局部座屈 領域における塑性変形による消費エネルギーが一致するように軸方 向変形 $d$ を求めることで構築される，以下に，本論で提案する軸ば ねの $f-d$ 関係の特徴をまとめる.

\section{(1) 平板部と角部の区別}

本論の検討対象である冷間プレス成形角形鋼管は，製造時の塑性 加工の影響で角部のみ強度が上昇するため, 平板部と角部とで材料 特性が大きく異なる ${ }^{19)}$. また形状の違いにより, 局部座屈の発生す る時期や耐力劣化挙動が平板部と角部で異なることが考えられる. これらの点に基づいて, 本論では平板部と角部で軸ばねの $f-d$ 関係 を区別してモデル化する．

\section{(2) 骨格曲線と履歴曲線}

軸ばねの $f-d$ 関係は, 図 3 に示すように骨格曲線と履歴曲線で構 成する ${ }^{20)}$. 引張側骨格曲線では，文献 18) と同様に亀裂発生から破 断に至るまでの耐力劣化を考慮する，圧縮側骨格曲線は，石田ら ${ }^{12)}$ と同様に局部座屈による耐力劣化を考慮する．局部座屈発生前の履 歴曲線には, バウシンガー効果を考慮できるように図 3 の細実線で 表す大井らの履歷則 ${ }^{21)}$ を採用する. 以上の点は既往の研究における 提案を組合せたものであるが，本論では新たに，図 3 の点線で表す 局部座屈発生後の履歴曲線を考慮する. これは, 3.4 節で示すように, 履歴曲線が局部座屈発生前後で異なる性状を示すことに基づく.

\section{(3) 曲げモーメント勾配を有する部材への適用}

本論では，短柱に軸力を作用させる有限要素法解析を行い，その 結果に基づいて平均応力-平均歪関係を定式化し， 2.2 節冒頭で述心゙ たように軸ばねの $f-d$ 関係に変換する，このとき，曲げモーメント 勾配を有する柱部材に適用できるように配慮する必要がある. 軸力 $f$ の変換には，材端溶接部の拘束による耐力の増大と，石田ら ${ }^{12)}$ と同 様に曲げモーメント勾配を考慮する．また，軸方向変形 $d$ の変換に は，文献 12)のように軸ばねの長さに依存する方法ではなく, 塑性 化領域および局部座屈領域の長さを考慮し, その領域内の塑性変形 による消費エネルギーが一致することに配慮する．詳細については 4 章で説明する.

なお，上述した(1)平板部と角部で軸ばねの $f-d$ 関係を区別してモ デル化すること, (2)局部座屈発生後の履歴曲線を考慮すること, (3) 塑性化領域または局部座屈領域の塑性変形による消費エネルギーを 等置して, 軸ばねの軸方向変形を求めることなどは, いずれも MS モデルを用いた既往の研究 ${ }^{12)}$, 13) とは異なり, 本論で新たに提案する ものである，これらの手法の導入は，後述する有限要素法解析結果 の観察や角形鋼管の材料特性の実状を踏まえて, より実際に近い状

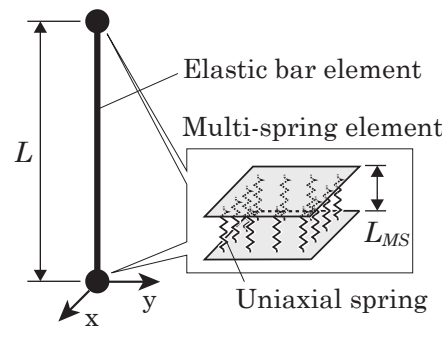

Fig. 1 Multi-spring model

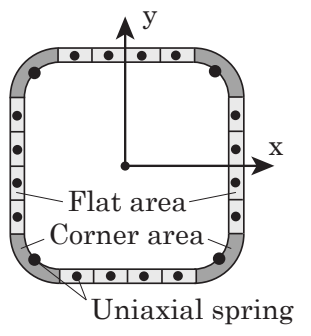

Fig. 2 Cross-section division

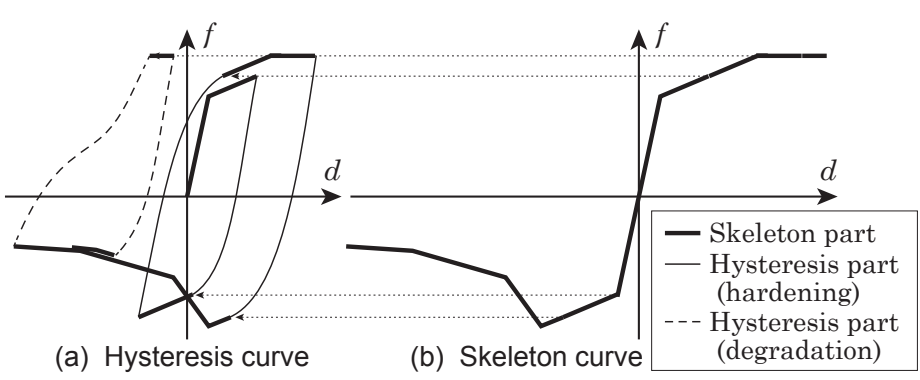

Fig. 3 Outline of force-deformation relationship of uniaxial spring 
況を再現することを意図している.

\section{3. 局部座屈発生後の応力-歪関係}

\section{1 短柱の有限要素法解析}

図 3 の軸ばねの $f-d$ 関係のうち, 圧縮側骨格曲線と局部座屈発生 後の履歴曲線を構築するために, 冷間プレス成形角形鋼管の短柱に 軸力を作用させる有限要素法解析を行い, 局部座屈発生後の応力一歪 関係を得る. 載荷履歴は, 局部座屈の進展に着目し, 圧縮側骨格曲 線の耐力劣化域の構築に用いる単調圧縮解析と, 局部座屈発生後の 除荷剛性の低下やスリップ挙動に着目し, 履歴曲線の構築に用いる 繰返し圧縮引張解析の 2 通りとする.

解析には非線形有限要素法解析プログラムAbaqus（version6.14） を用いる. 図 4 に解析モデルを示す. 外径 $D$ を $200 \mathrm{~mm}$ で一定とし, 長さ $L_{0}$ と板厚 $t$ をパラメータとしている. 角部の外側曲率半径 $R$ は, 冷間プレス成形角形鋼管を想定して板厚 $t$ の 3.5 倍としている. 解析 モデルはソリッド要素で構成し，要素の分割は，材軸方向と幅方向 に $6 \mathrm{~mm}$ ピッチ, 板厚方向に $2.5 \sim 3 \mathrm{~mm}$ ピッチとする.

鋼材の応力-歪関係は, 付録 1 に示寸ように $490 \mathrm{~N} / \mathrm{mm}^{2}$ 級の冷間 プレス成形角形鋼管の素材試験結果 ${ }^{22)}$ を参考にして定めたものを, 平板部と角部に別々に与える. 降伏条件にはMises の降伏条件を, 硬化則には混合硬化則を適用している．移動硬化と等方硬化の比率 やその特性は，付録 2 に示すように軸力と曲げを与えた冷間プレス 成形角形鋼管柱に関する既往の実験結果 ${ }^{22)}$ と有限要素法解析結果が 概ね対応するように試行錯誤的に定めている。また，文献 23)，24) の知見によると, 局部座屈発生後の耐力劣化域の挙動に及ぼす残留 応力の影響は小さいことから, 本論では残留応力は考慮しない.

境界条件は, 図 4 に示すように上下端の全要素の自由度を断面の 図心に変位等置し, 戝心の自由度を下端ですべて拘束し, 上端で材 軸方向の変位だけを自由にする. 載荷は, 上端の図心に材軸方向の 強制変位を与える形式とする，局部座屈を考慮するために，上端の 図心に圧縮軸力だけを作用させる座屈固有值解析を行い, 1 次の座屈 モードと同一形状の面外変形を初期不整として与える. 面外変形量 の最大值を $1 \mathrm{~mm}$ （断面せい $D$ の $0.5 \%$ ) とする.

\section{2 単調圧縮解析}

解析パラメータは, 幅厚比 $D / t(16.7,22.2,26.7,33.3,40.0)$, アスペクト比 $L_{0} / D(0.75,1,2,3)$ とする. 図 5 に, 単調圧縮解析 による応力一歪関係を, 平板部と角部で分けて示寸. ここで応力とは, 局部座屈による面外变形が最大となる断面 (以下, 最大耐力規定点 ${ }^{9}$ ) において, 平板部もしくは角部に含まれる全要素の材軸方向応力を 要素の断面積で重み付き平均した值である. また, 歪は局部座屈領 域における軸方向変形を局部座屈領域の長さで除した值である。た だし, 局部座屈領域の長さは, 最大応力到達後に弾性除荷される領 域の長さを解析モデルの長さ $L_{0}$ から減じたものである. 単調圧縮解 析では, 図 6(a) に示寸伸張型と, 図 6(b) に示寸不伸張型の局部座屈 モードが確認された。 また $L_{0} / D=2, D / t=22.2 \sim 40.0$ のケースは 1 波の局部座屈が，それ以外のケースは半波の局部座屈が生じた。

図 5 より, 角部のほうが平板部よりも最大応力到達時の歪が大きく, その後の応力の劣化が緩やかなことがわかる. 伸張モードが生じた ケースでは, 不伸張モードが生じたケースよりも応力の劣化が緩や かであることが確認できる．また，1波の局部座屈が生じたケースで
は, 歪が 0.1 程度以降において片方の半波分の局部座屈だけに変形 が集中したため，半波の局部座屈が生じたケースと比べて歪の増加 が抑制されている，さらに，局部座屈モードが同じであれば $L_{0} / D$ が 劣化挙動に及ぼす影響は小さいと言える.

\section{3 単調圧縮時の応力-歪関係の定式化}

軸ばねの圧縮側骨格曲線の元になる応力一歪関係を構築するため, 図 5 に示す単調圧縮解析結果を, 図 7 の太点線で表すように 5 折線 でモデル化する. 図 5 の解析結果から, 応力上昇率 $S$ (最大応力を 降伏応力で除した值), 歪塑性率 $\mu_{0}$ (最大応力時の歪を降伏歪で除し た值), 劣化域の遷移点耐力を決める係数 $T, T_{2}$, 劣化域の岡性 $E_{d 1}$, $E_{d 2}, E_{d 3}$ の 7 項目を同定する. ただし，これらの項目のうち $T, T_{2}$ を抽出する点は, 応力一歪関係の接線剛性の変化率が明瞭に大きくな る点としている. なお, 片持ち形式の柱に発生する局部座屈波数が, 局部座屈発生後の耐力劣化挙動に及ぼす影響が小さいこと ${ }^{25)}$ に基づ いて, 本論では図 5 のうち半波の不伸張モードが生じた解析結果を 対象とする.

図 8 に，上述した 7 項目と基準化幅厚比 $\alpha$ との関係をプロットで 示す.ここで, 基準化幅厚比 $\alpha$ は (2) 式で表される.

$$
\alpha=\left(\frac{D}{t}\right)^{2} \frac{\bar{\sigma}_{y}}{E}
$$

ただし， $\bar{\sigma}_{y}$ は角形鋼管の平均降伏応力で, 平板部・角部の断面積 $A_{f} \cdot A_{c}$, 平板部・角部の降伏応力 $\sigma_{f y} \cdot \sigma_{c y}$ を用いて (3) 式で算出寸る.

$$
\bar{\sigma}_{y}=\frac{A_{f} \cdot \sigma_{f y}+A_{c} \cdot \sigma_{c y}}{A_{f}+A_{c}}
$$

図 8 中のプロットを以下の (4) (10) 式で近似する.ただし, 平板 部の $\mu_{0}$ のプロットは，平板部と角部を区別せずに得られた文献 9)

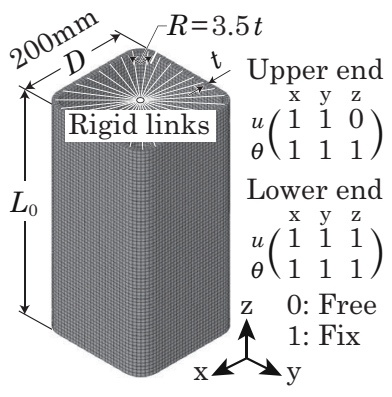

Fig. 4 Finite element model of stub column

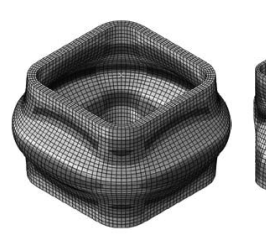

(a) Extended mode

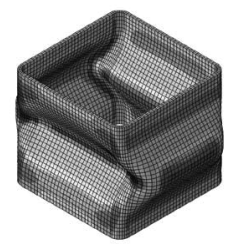

(b) Non-extended mode
Fig. 6 Local buckling modes under compression

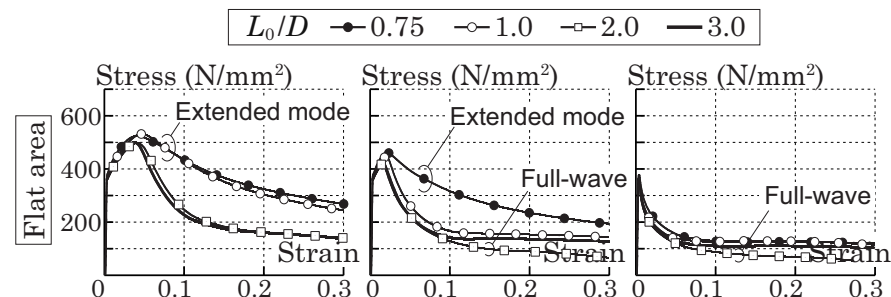

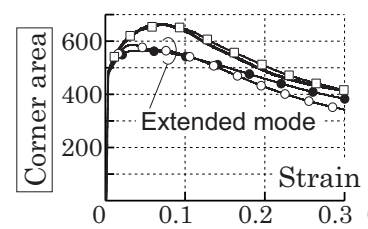

(a) $D / t=16.7$ $(t=12 \mathrm{~mm})$

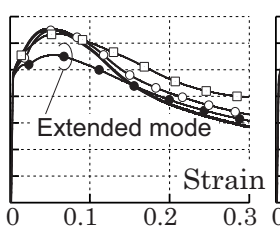

(b) $D / t=22.2$

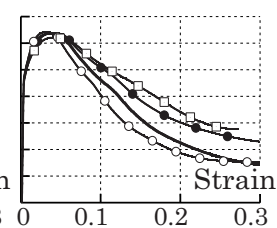

(c) $D / t=33.3$

Fig. 5 Finite element analysis results under monotonic compression loading 


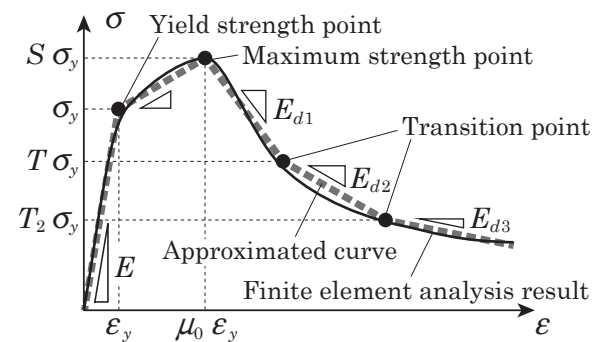

Fig. 7 Approximated curve of stress-strain relationship under monotonic compression loading

の実験式とよく対応しており，本論では文献 9) の式を採 用する。

平板部 : $S=\frac{6.5}{\alpha+4.5}+0.1 \quad$ 角部 : $S=1.341$

平板部 : $\begin{cases}\mu_{0}=\frac{17.4}{\alpha}-9.6 & {\left[0.398 \leq \frac{1}{\alpha} \leq 1.39\right]} \\ \mu_{0}=\frac{4.8}{\alpha}-0.52 & {\left[1.39 \leq \frac{1}{\alpha}<4.34\right]}\end{cases}$

角部 : $\mu_{0}=\frac{16}{\alpha+0.2}+8$

$(5)$

平板部 : $\frac{T}{S}=0.447 \quad$ 角部 $: \frac{T}{S}=-0.131 \alpha+0.753$

平板部 : $\frac{T_{2}}{S}=0.330 \quad$ 角部 $: \frac{T_{2}}{S}=-0.114 \alpha+0.527$

(6)

平板部 : $\frac{E_{d 1}}{E}=-0.0150 \alpha-0.0146$ 角部 $: \frac{E_{d 1}}{E}=-0.0046 \alpha-0.0053$

平板部 $: \frac{E_{d 2}}{E}=-0.00492$ 角部 $: \frac{E_{d 2}}{E}=-0.0010 \alpha-0.0026$

平板部 : $\frac{E_{d 3}}{E}=-0.000452$ 角部 $: \frac{E_{d 2}}{E}=-0.000590$

\section{4 繰返し圧縮引張解析}

繰返し圧縮引張解析における解析パラメータには, 幅厚比 $D / t$ と 軸方向変形の載荷履歴を採用する. アスペクト比は $L_{0} / D=3$ の場合 だけに限定する。これは, 図 5 の単調圧縮解析結果では, $L_{0} / D=3$ の

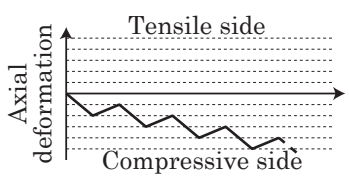

(a) Loading protocol 1

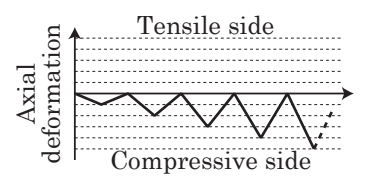

(b) Loading protocol 2
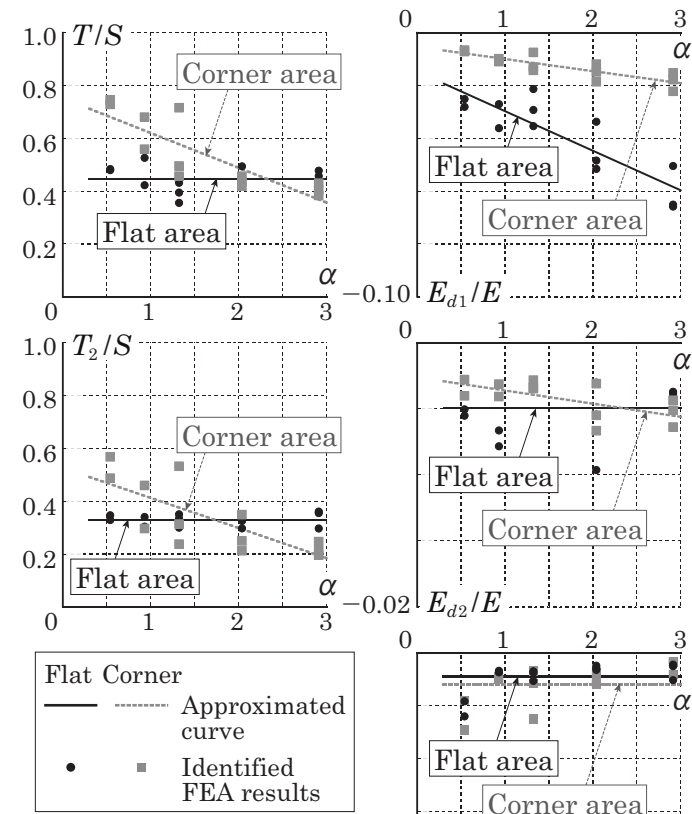

${ }_{-0.02} E_{d 2} / E \ldots \ldots \ldots \ldots \ldots \ldots \ldots \ldots$
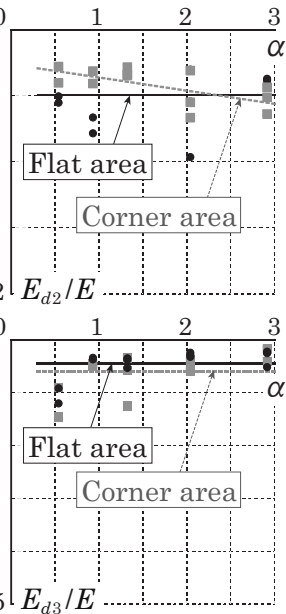

Fig. 8 Identified parameters under monotonic compression loading

ケースのみ, すべての幅厚比で半波の不伸張モードが確認されたこ と，ならびに局部座屈モードが同じであればアスペクト比の違いが 劣化域の挙動に及ぼす影響は小さく, この傾向は繰返し載荷時にも あてはまると考えられることによる。

軸方向変形の載荷履歴は図 9 に示す 4 種類とする. 載荷履歴 1 は, 圧縮と引張の半サイクルでの変形増分の比が $2: 1$ であり, 除荷後に引 張変形が十分に進展しない領域での挙動に着目したものである。載 荷履歴 2 は圧縮と引張の半サイクルでの変形増分の比が等しく, 除 荷後に引張変形が十分に進展した領域での挙動に着目したものであ る. 載荷履歴 3 は正負交番漸増振幅であり, 引張側骨格曲線上での 挙動に, 載荷履歴 4 は正負交番漸減振幅であり, 局部座屈が大きく

Fig. 9 Loading protocol for finite element analysis under cyclic axial loading

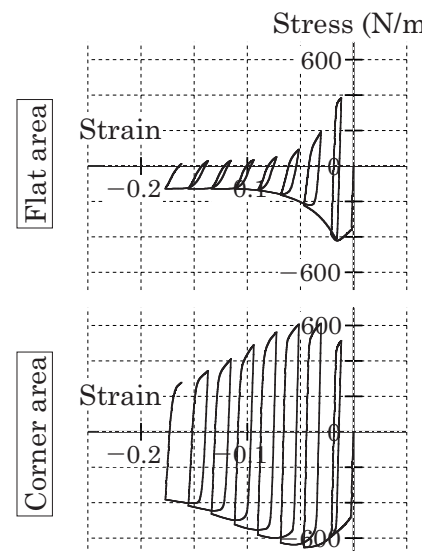

(a) Loading protocol 1

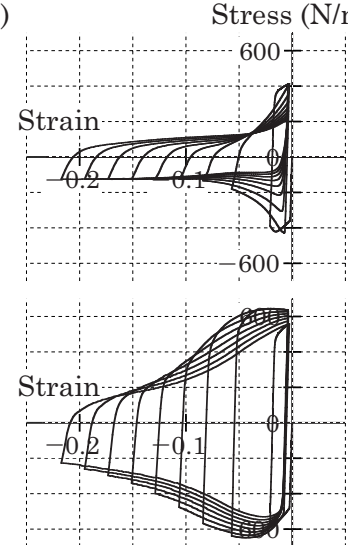

(b) Loading protocol 2

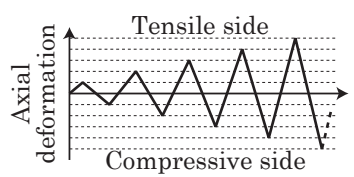

(c) Loading protocol 3

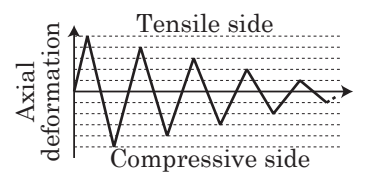

(d) Loading protocol 4

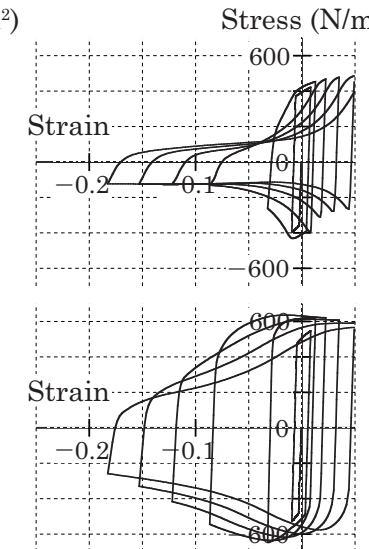

(c) Loading protocol 3

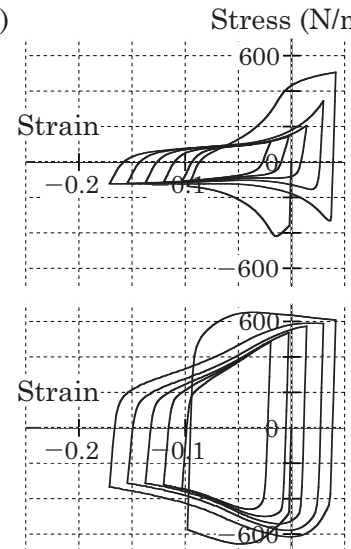

(d) Loading protocol 4

Fig. 10 Finite element analysis results under cyclic axial loading $(D / t=22.2)$ 


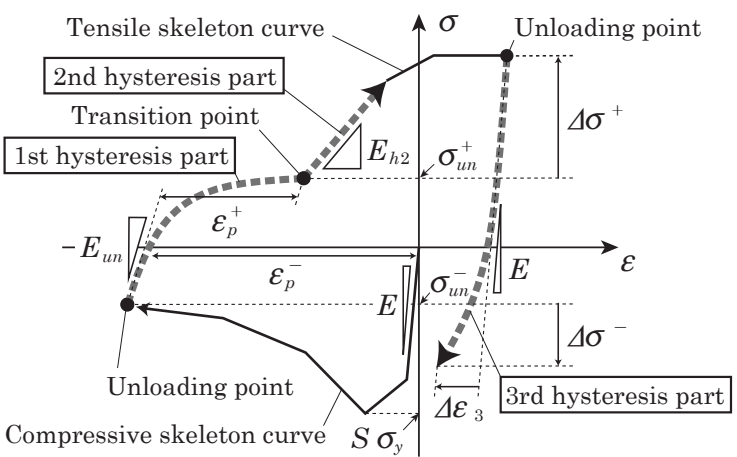

Fig. 11 Approximated curve of stress-strain relationship under cyclic axial loading
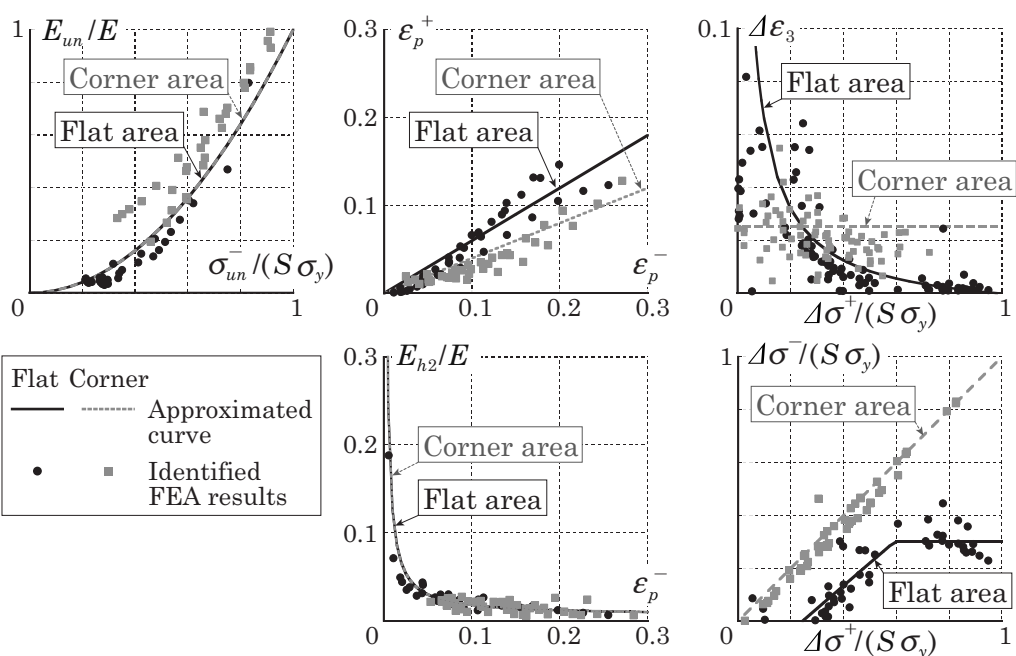

Fig. 12 Identified parameters under cyclic axial loading

平板部 $\cdot$ 角部 $: \frac{E_{u n}}{E}=\left(\frac{\sigma_{u n}^{-}}{S \cdot \sigma_{y}}\right)^{2}$

平板部 : $\varepsilon_{p}^{+}=0.6 \varepsilon_{p}^{-} \quad$ 角部 $: \varepsilon_{p}^{+}=0.4 \varepsilon_{p}^{-}$

平板部・角部 $: \frac{E_{h 2}}{E}=\frac{0.0012}{\varepsilon_{p}^{-}}+0.006$

挙動が見られる（図 10(b)，(c)，(d))。

・引張側のスリップ挙動の後は, 接線剛性が再び増大して引張降伏 する (図 10(c)).

・引張降伏した後, 再び圧縮側に載荷した場合, その前のサイクル の除荷点応力よりも大きな応力に達する (図 10(b), (c), (d)).

ここでは $D / t=22.2$ の結果だけを示しているが, これ以外の幅厚比 $D / t$ に対しても上記と同様の傾向が見られた.

\section{5 繰返し載荷時の応力-歪関係の定式化}

局部座屈発生後の軸ばねの履歴曲線の元になる応力一歪関係を構築 するため, 3.4 節で述べた繰返し圧縮引張解析結果の特徴を考慮して, 図 11 の太点線で表すように第一・第二・第三履歴曲線に分類してモ デル化する.

第一履歴曲線では, 圧縮側劣化域で除荷発生後から引張側のスリッ プ挙動までの応力ー歪関係を Ramberg-Osgood 曲線 (以下, RO 曲線) でモデル化する. 除荷剛性 $E_{u n}$ は除荷点応力 $\sigma_{u n}^{-}$に応じて与える. また遷移点の応力 $\sigma_{u n}^{+}$は除荷点応力 $\sigma_{u n}^{-}$と同じ大きさとし, 除荷点 から遷移点までの塑性歪 $\varepsilon_{p}^{+}$は, 除荷点における圧縮歪 $\varepsilon_{p}^{-}$に応じて 与える.

第二履歴曲線は遷移点から引張側骨格曲線までの応力一歪関係をモ デル化したもので, 引張塑性変形の進行する領域が局部座屈領域以 外に拡大寸る挙動を示寸区間である. 第二履歴曲線の接線剛性 $E_{h 2}$ は $\varepsilon_{p}^{-}$に応じて与える.

第二履歴曲線上または引張側骨格曲線上で除荷が発生すると, RO 曲線で表す第三履歴曲線に移行する. 第三履歴曲線の除荷剛性は中 ング係数 $E$ とし, 歪増分は $\Delta \varepsilon_{3}$ とする. また第三履歴曲線では圧縮

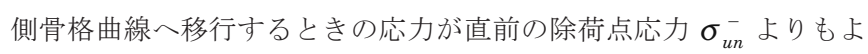
りも $\Delta \sigma^{-}$だけ回復するものと考える. $\Delta \varepsilon_{3}$ と $\Delta \sigma^{-}$は, 遷移点からの 引張耐力増分 $\Delta \sigma^{+}$に応じて与える.

図 10 の繰返し圧縮引張解析結果から, 上述した第一, 第二, 第三 履歴曲線を定める 5 項目を同定して図 12 にプロットする.これらの プロットの近似式として以下の $(11) \sim(15)$ 式を用いる.
平板部 : $\Delta \varepsilon_{3}=\frac{0.009}{\Delta \sigma^{+} /\left(S \sigma_{y}\right)+0.02}-0.009$ 角部 : $\Delta \varepsilon_{3}=0.025$

平板部 : $\left\{\begin{array}{l}\frac{\Delta \sigma^{-}}{S \cdot \sigma_{y}}=0.86 \frac{\Delta \sigma^{+}}{S \cdot \sigma_{y}}-0.21\left[0.25 \leq \frac{\Delta \sigma^{+}}{S \cdot \sigma_{y}} \leq 0.6\right] \\ \frac{\Delta \sigma^{-}}{S \cdot \sigma_{y}}=0.30 \\ {\left[0.6<\frac{\Delta \sigma^{+}}{S \cdot \sigma_{y}}\right]}\end{array}\right.$ 角部 $: \frac{\Delta \sigma^{-}}{S \cdot \sigma_{y}}=\frac{\Delta \sigma^{+}}{S \cdot \sigma_{y}}$

\section{4. 軸ばねの軸力ー軸方向変形関係}

\section{1 応力-歪関係から軸力-軸方向変形関係への変換}

軸ばねの軸力 $f$-軸方向変形 $d$ 関係を構築するためには，2.2 節で 述べたように，角形鋼管柱端の応力に軸ばねの断面積 $A$ を乗じて軸 力 $f$ を求め, 塑性化領域または局部座屈領域で塑性変形による消費工 ネルギーが一致するように軸方向変形 $d$ を求める必要がある. 本論 では, 2.2 節の (3)で述べたように軸力 $f$ と軸方向変形 $d$ の変換にあたつ て以下の 3 点を考慮する.

・通しダイアフラム形式の角形鋼管柱端は, 図 13 に示すように溶接 部によって柱の周方向の歪が拘束されているため, 軸方向の降伏 応力や最大応力が増大する (4.2 節 (1) で詳述).

- 3 章で定式化した局部座屈発生後の応力一歪関係は, 最大耐力規定 点 ${ }^{9)}$ (局部座屈による面外変形が最大となる断面）の応力に基づい ているが, 曲げモーメント勾配を有する場合, 材端の応力は最大 耐力規定点より大きい ${ }^{12)}$ (4.3 節（1）で詳述).

・軸ばねの塑性変形（増分）による消費エネルギー（増分）は，塑 性化領域や局部座屈領域における軸方向の塑性歪（増分）による 消費エネルギー（増分）と一致する（4.3 節（2）・(3）で詳述). 以下に, 引張側骨格曲線・圧縮側骨格曲線 - 圧縮側最大耐力到達後 の履歴曲線・圧縮側最大耐力到達までの履歴曲線の構築方法を示す.

\section{2 引張側骨格曲線}

\section{（1）柱端における拘束の影響}

引張側骨格曲線の構築にあたっては，4.1節の 1 点目で述べたよう 
に角形鋼管柱端の降伏応力や最大応力が，溶接部の拘束により増大 することを考慮する. 全塑性モーメント到達時における柱端の応力 が，溶接部の拘束を受けてどの程度増大寸るのかを確認するために， 5.1 節で後述する有限要素法解析モデルに対して片曲げモーメントを 単調に与える解析を行う。鋼材の応力一歪関係は完全弾塑性型とし, 幅厚比 $D / t$ を 16.7 と 40.0 , せん断スパン比 $L / D$ を 2 と, 軸力比 $n$ を 0 と 0.3 , 載荷方向を $0^{\circ}$ と $45^{\circ}$ とする.

図 14 に, $D / t=40.0, L / D=2, n=0$, 載荷方向 $0^{\circ}$ の場合について, 柱端の軸方向の平均応力と柱の変形角との関係を示す.ただし, 縦 軸の值は柱端における引張側の平板部または角部に含まれる全要素 の軸方向応力を要素の断面積で重み付き平均した值を, 降伏応力 $\sigma_{y}$ で除したものである. 図 14 より, 平板部・角部の平均応力 $\sigma$ は降 伏応力 $\sigma_{y}$ の $1.09 \sim 1.14$ 倍に漸近していることが確認できる. 図 14 以外のパラメータに対しても同様の傾向が確認された.

ここで, 完全弾塑性型の応力一歪関係を有し, Mises の降伏条件に 従う材料について考える. 板厚方向の拘束がなく平面応力状態(板厚 方向の応力が 0)であり, 周方向の歪が完全に拘束されている場合, 材軸方向の応力は降伏応力 $\sigma_{y}$ の $2 / \sqrt{3}(\fallingdotseq 1.15)$ 倍まで増大寸る. 図 14 の結果はこの值よりもわずかに小さく, 周方向の歪が完全に拘束 されていないことを示している. 以上の検討結果に基づいて, 本論 では溶接部の拘束を受ける柱端の降伏応力と最大応力は, 引張試験 等で得られる 1 軸応力状態における降伏応力と最大応力に対して 1.1 倍に増大するものと考える。

\section{(2) 引張側骨格曲線}

文献 18) と同様に, 亀裂・破断による耐力劣化挙動を考慮するた めに，軸ばねの引張側骨格曲線を図 15 のように与える。本節 $(1$ )の 検討に従って, 降伏耐力 $f_{y}$ と最大耐力 $f_{u}$ は, 1 軸応力状態における 降伏応力と最大応力を 1.1 倍し, さらに軸ばねの断面積 $A$ を乗じた 值とする. また, 第 2 分枝剛性は弾性剛性 $k_{0}$ の 0.01 倍とする.

亀裂発生に伴う引張側劣化開始点は, 軸ばねの引張側の累積塑性 変形が $d_{c}$ に達した点とする. したがって, 劣化開始点は引張側骨格 曲線または履歴曲線上に現れる. 劣化域では, 軸方向変形 $d$ の増大 に伴って一定の剛性 $k_{f}$ で軸力 $f$ が低下し, $f=0$ になると軸ばねが破 断したとみなす。破断後に引張側の変形が進行すると破面が開いて $f=0$ のまま軸方向変形 $d$ が増大し, その後, 軸方向変形 $d$ が圧縮側 に転じると破断面が閉じていき, $d$ が破断発生時の值に戻ると破面が 再接触して圧縮力を負担する.

\section{3 圧縮側骨格曲線および圧縮側最大耐力到達後の履歴曲線}

\section{（1）曲げモーメント勾配による影響}

圧縮側骨格曲線と圧縮側最大耐力到達後の履歴曲線を構築するた め, 3 章で定式化した最大耐力規定点における局部座屈発生後の応力 一歪関係を，曲げモーメント勾配の影響を考慮して材端の応力に変換

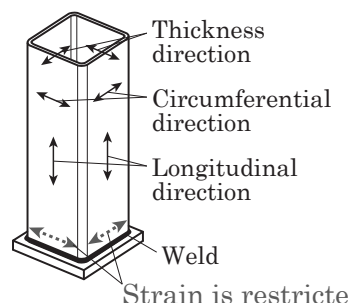

Fig. 13 Weld at end of column

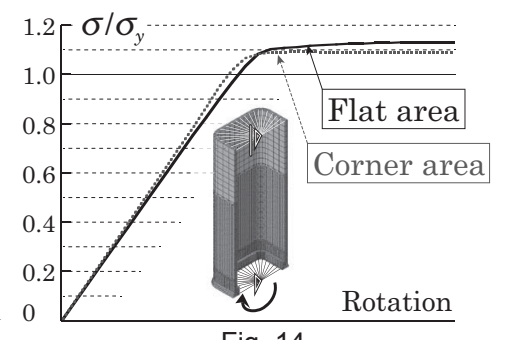

Longitudinal stress at end of column

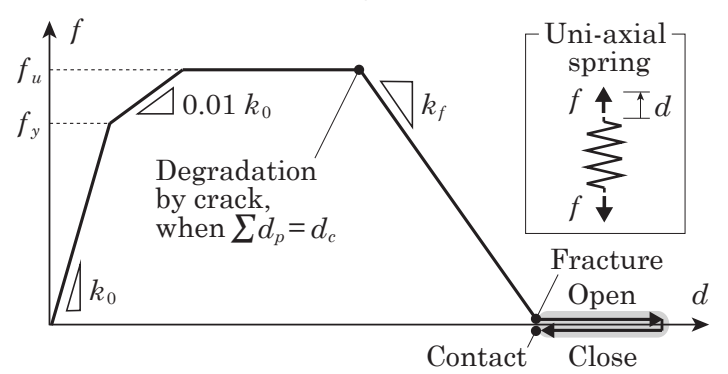

Fig. 15 Tensile skeleton curve of uniaxial spring

する. 文献 12) と同様に, 文献 9) の知見に基づいて, 局部座屈領域 長さは角形鋼管の外径 $D$ の 0.8 倍とし, 最大耐力規定点は局部座屈 領域長さの中央断面と考え, 次式によって材端の応力 $\sigma^{*}$ を求める.

$$
\sigma^{*}=\frac{\sigma}{1-0.4 D / L}
$$

圧縮側骨格曲線と圧縮側最大耐力到達後の履歴曲線におけるすべて の耐力に対して (16) 式による換算を適用する．ただし，圧縮側骨格 曲線における降伏耐力については, 1 軸応力状態での降伏応力の 1.1 倍した值と (16) 式による值の小さい方に基づいて定める.

\section{（2）最大耐力到達時の軸ばねの軸方向変形}

4.1 節の 3 点目に従って圧縮側骨格曲線における最大耐力到達時の 軸ばねの軸方向変形 $d_{0}$ を求める. 図 $16(\mathrm{a})$ に, 最大曲げモーメント $M_{\max }$ に達したときの圧縮縁における軸方向の塑性歪分布を点線で示 す. 本論では，このときの塑性化領域内の応力が (16) 式で与えられ， 塑性歪の平均值が最大耐力規定点における塑性歪 $\left(\mu_{0}-S\right) \varepsilon_{y}$ と一致す るものと仮定し, さらに塑性化領域の長さ $L_{y p}$ が柱端から曲げモーメ ントが $\left(M_{y n}+M_{p n}\right) / 2$ になる位置までの範囲とみな寸ことで, 簡略的 に最大耐力到達時の軸ばねの塑性変形 $d_{0 p}$ を次式で求める.

$$
d_{0 p}=\left(\mu_{0}-S\right) \varepsilon_{y} \cdot L_{y p}
$$

一方で, 圧縮側骨格曲線において最大耐力到達時の軸ばねの弾性変 形 $S \cdot d_{y}$ は次式で表される.

$$
S \cdot d_{y}=\frac{\frac{S \cdot A \cdot \sigma_{y}}{1-0.4 D / L}}{k_{0}}=\frac{S \cdot \varepsilon_{y} \cdot L_{M S}}{1-0.4 D / L}
$$

(17) 式の $d_{0 p}$ に (18) 式の $S \cdot d_{y}$ を加えることで, 最大耐力到達時の変 形 $d_{0}$ が次式で求められる.

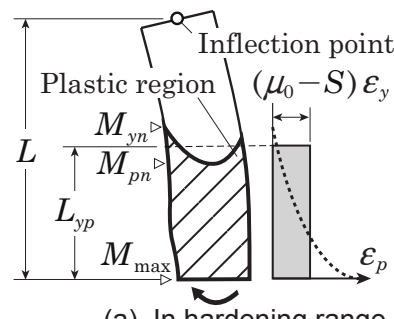
(a) In hardening range $\quad$ (b) In deteriorating rang
Fig. 16 Assumption of strain distribution of column

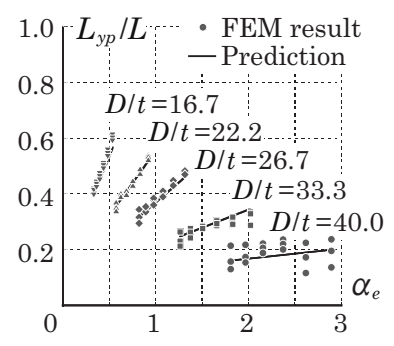

Fig. 17 Length of plastic region

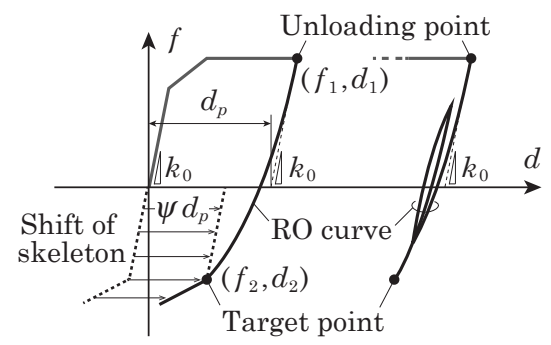

Fig. 18 Hysteresis curve ${ }^{21), 26)}$ 


$$
d_{0}=\left\{\left(\mu_{0}-S\right)\left(1-0.4 \frac{D}{L}\right) \frac{L_{y p}}{L_{M S}}+S\right\} d_{y}
$$

塑性化領域の長さ $L_{y p}$ に関しては, 5.1 節で後述する有限要素法解 析モデルに軸力と片曲げモーメントを与えた結果に基づいて，曲げ モーメントが $\left(M_{y n}+M_{p n}\right) / 2$ になる位置までの距離を求めると図 17 の 灰色プロットが得られる. 図の横軸は基準化等価幅厚比 $\alpha_{e}$ で, (20) 式により定義される ${ }^{12)}$.

$$
\alpha_{e}=\frac{1+k^{2}}{2}\left(\frac{D}{t}\right)^{2} \frac{\bar{\sigma}_{y}}{E}
$$

ここで， $k$ は軸力を考慮した全塑性状態においてウェブの中で圧縮力 を受ける面積の割合である. 図 17 のプロットを(21) 式で近似する ことで，塑性化領域の長さ $L_{y p}$ を求めることができる.

$$
\frac{L_{y p}}{L}=\left(\frac{0.45}{\alpha_{e 0}+0.1}-0.2\right)\left(\alpha_{e}-\alpha_{e 0}\right)+\left(0.45-0.16 \alpha_{e 0}\right)
$$

ただし， $\alpha_{e 0}$ は軸力比が $0(k=0.5)$ のきの基準化等価幅厚比である. (21) 式による塑性化領域の長さ $L_{y p}$ は軸力の影響を受けるため, 変動 軸力下では逐一 $L_{y p}$ を算定する必要がある.

\section{（3）最大耐力到達以降の軸ばねの軸方向変形}

上記 (2) と同様に, 4.1 節の 3 点目に従って最大耐力到達以降の圧 縮側骨格曲線と履歴曲線における軸ばねの軸方向変形の増分を求め る. 3 章で定式化した応力-歪関係では局部座屈領域の平均歪を採用 していることを考慮すると, 最大耐力到達以降の塑性歪増分 $\Delta \varepsilon_{p}$ は 図 16(b) のように局部座屈領域 ( $0.8 D$ の範囲) に一様分布するものと みなせる. 局部座屈領域内の応力が (16) 式で与えられると考えると, 塑性変形の増分 $\Delta d_{p}$ は $\Delta \varepsilon_{p} \cdot 0.8 D$ となり, 圧縮側骨格曲線の耐力劣 化域では応力増分 $\Delta \sigma$ と $(8) \sim(10)$ 式の $E_{d i}(i=1 \sim 3)$ を用いて $\Delta d_{p}$ は 次式で求められる.

$$
\Delta d_{p}=\Delta \varepsilon_{p} \cdot 0.8 D=\frac{\Delta \sigma}{E}\left(\frac{E}{E_{d i}}-1\right) 0.8 D
$$

上式に, 応力増分 $\Delta \sigma$ に対する軸ばねの弾性変形増分を加えることで, 軸ばねの変形増分が $(23)$ 式で求められる.

$$
\Delta d=\frac{\Delta \sigma}{E}\left\{\left(\frac{E}{E_{d i}}-1\right) 0.8 D+\frac{L_{M S}}{1-0.4 D / L}\right\}
$$

(23) 式の応力増分 $\Delta \sigma$ に (16) 式の変換を適用することで, 圧縮側骨 格曲線の劣化域における接線剛性 $k_{d i}(i=1 \sim 3)$ が次式で求められる.

$$
k_{d i}=k_{0}\left\{\left(1-0.4 \frac{D}{L}\right) \frac{0.8 D}{L_{M S}}\left(\frac{E}{E_{d i}}-1\right)+1\right\}^{-1}
$$

最大耐力到達以降の履歴曲線において, 第一, 第二履歴曲線の接 線剛性を定める变数 $E_{u n}, E_{h 2}$ に対しても上記と同様の変換を行うこ とで, 図 3(a)の点線で表す軸ばねの軸力一軸方向変形関係の履歴曲線 を構築することができる.

\section{4 圧縮側最大耐力到達までの履歴曲線}

2.2 節の(2)で述べたように, 圧縮側骨格曲線の最大耐力到達までの 履歴曲線では, バウシンガー効果を考慮するために大井らの履歷則 を適用する. 大井らの履歷則 ${ }^{21)}$ では図 18 左側に示すように, 降伏 後の骨格曲線上において除荷が発生すると, 塑性変形量 $d_{p}$ の $\psi$ 倍だ け反対側の骨格曲線を横軸と平行に移動させ, その骨格曲線上の目 標点までの履歷曲線を, 接線剛性を弾性剛性 $k_{0}$ とする RO 曲線によっ て表す．また RO 曲線上で除荷と再載荷が交互に発生した場合は図 18 右側に示寸小ループを描く履歴則 ${ }^{26)}$ を適用する. RO 曲線上の点 $(f, d)$ は除荷開始点を $\left(f_{1}, d_{1}\right)$, 目標点を $\left(f_{2}, d_{2}\right)$ とすれば (25) 式の関 係で表される ${ }^{26)}$.

$$
\left(f-f_{1}\right)\left(1+\beta\left|f-f_{1}\right|^{\gamma-1}\right)=k_{0}\left(d-d_{1}\right)
$$

(25) 式中の $\gamma$ は RO 曲線の丸み (曲率) を定める係数で, $\gamma$ に大きな 值を与えると $\mathrm{RO}$ 曲線の曲率が大きくなる. また (25) 式中の係数 $\beta$ は (26) 式で表される ${ }^{26)}$.

$$
\beta=\frac{1}{\left|f_{2}-f_{1}\right|}\left\{\frac{k_{0}\left(d_{2}-d_{1}\right)}{f_{2}-f_{1}}-1\right\}
$$

\section{MS モデルの妥当性検証}

本章では，4 章までに構築した MS モデルの妥当性を検証するた めに, MS モデルによる解析結果を, 有限要素法解析結果や既往の実 験結果 ${ }^{22)}$ と比較する.

\section{1 有限要素法解析結果との比較}

\section{(1) 解析の概要}

局部座屈発生後の耐力劣化挙動の追跡精度を確認するため, MS モデルによる解析を有限要素法解析と比較する. 解析パラメータは, 幅厚比 $D / t （ 16.7,22.2,26.7,33.3,40.0)$, せん断スパン比 $L / D(2$, $4,6)$, 軸力比 $n(0,0.1,0.2,0.3,0.4,0.5)$ とする. 角形鋼管の 外径 $D$ は $200 \mathrm{~mm}$ とし, 載荷方向は $0^{\circ}$ 方向(図 19 の $\mathrm{y}$ 軸まわり)に 限定する.

有限要素法解析では, 図 19 左側に示すように幅方向に $1 / 2$ に切断 したモデルを用いる. 角形鋼管の母材の他に, 図 19 右側に示寸溶接 詳細に従って溶接金属や裏当て金を考慮する．角形鋼管母材と溶接 金属には付録 1 で示した応力一歪関係を与え, 裏当て金には母材 (平 板部) と同じ応力一歪関係を与える。降伏条件にはMises の降伏条件 を，硬化則には混合硬化則を適用する．3.1節で述べたように，硬化 特性は有限要素法解析結果が文献 22) の実験結果と概ね対応するよ うに定めている(付録 2 参照).

一方で, MS モデルでは表 $\mathrm{A} 1$ の降伏応力 $\sigma_{y}$ と引張強さ $\sigma_{u}$ を平板 部と角部にそれぞれ与える. 軸ばねの長さ $L_{M S}$ は, 局部座屈領域長 さと等しい $0.8 D(=160 \mathrm{~mm})$ とする.

両解析とも, 両端を単純支持した柱の一端に軸力 $N$ を, 他端に曲 げモーメント $M$ を作用させて変形角 $\theta$ を生じさせる. 載荷は無軸力 下の全塑性モーメント $M_{p}$ に対応する弾性限変形角 $\theta_{p}$ で制御し, 図

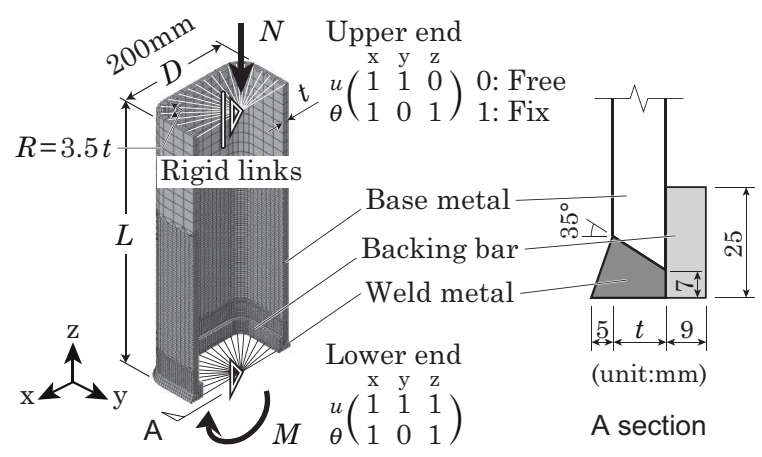

Fig. 19 Finite element model under bending moment and axial force

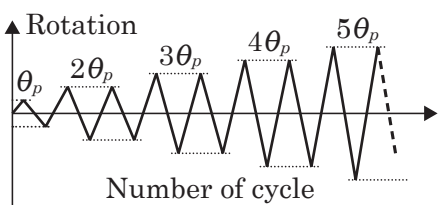

Fig. 20 Loading protocol for rotation at the end of column 
20 に示すように $\theta_{p}$ の整数倍の変形角を 2 サイクルずつ漸増させなが ら正負交番に与える.

\section{(2) 比較 ·考察}

図 21 に, 柱端曲げモーメント $M$-変形角 $\theta$ 関係ならびに各振幅の ピーク時における曲げモーメント $M_{\text {peak }}$-軸方向変形 $\delta_{N}$ 関係を, 有限 要素法解析と MS モデルによる解析で比較して示寸. 各図の縦軸の 值は，無軸力下の全塑性モーメント $M_{p}$ で無次元化したものである. また $M-\theta$ 関係の横軸の值は, 変形角 $\theta$ を $M_{p}$ 到達時の弾性変形角 $\theta_{p}$ で無次元化したものである. 図中には，MS モデルの解析で圧縮側最 大耐力到達までの履歷曲線に適用した骨格曲線のシフト量を定める 係数 $\psi$ と $\mathrm{RO}$ 曲線の曲率を定める係数 $\gamma$ の值を示している. $\psi$ と $\gamma$ の值については, MS モデルの解析と有限要素法解析の対応が良くな るように試行錯誤的に与えている. ただし, 本論の有限要素法解析 では図 A1 の応力ー歪関係 1 種類だけを用いているため, 寸べてのケー スで $\gamma=10$ を採用している.

まず，幅厚比 $D / t$ を変化させた場合について図 $21(\mathrm{a}) \sim(\mathrm{c})$ を比較 すると, 幅厚比が小さい場合に MS モデルの方が耐力が低くなって いる. 特に図 21 (a) の $D / t=16.7$ の場合は, ここで示していない解析 ケースを含む全ケースの中で最も耐力の差が大きく, この一因とし ては伸張モードが生じたことが考えられる.

一方, せん断スパン比 $L / D$ を変化させた場合について図 21 の (b) と (d) を比較すると, 図 21(d) の $L / D=2$ で $\mathrm{MS}$ モデルの最大耐力が 若干大きめになっていること, ならびに終盤の耐力劣化に若干の差 異が見られることが確認できる. 最大耐力の差異は, せん断スパン
比 $L / D$ が小さい場合にせん断力の影響で有限要素法解析結果の耐力 が抑制されたこと，ならびに MS モデルでせん断スパン比に関わら ず最大耐力規定点を材端から $0.4 D$ の位置と定めたことなどに起因す るものと考えられる．ただし，図 21(d) から，MS モデルの解析と有 限要素法解析との差異はそれほど大きくなく, $L / D=2$ の場合でも本 論で提案した MS モデルを適用することができるものと考えられる. なお, $L / D=6$ の場合については, $L / D=4$ の場合と同様の傾向が確認 されたため, ここでは結果を割愛する.

また, 軸力比 $n$ を変化させた場合について図 21 の (b), (e), (f) を 比較すると, $D / t=22.2$ で軸力比 $n$ が大きい場合には, 伸張モード が生じたことに起因して MS モデルの耐力が若干低めになっている. ここでは, 軸力比 $n$ が 0 から 0.5 までの範囲で MS モデルの妥当性 を確認したが，これをこえる範囲の妥当性については別途検討が必 要である.

\section{2 実験結果との比較}

\section{（1）実験・解析の概要}

5.1 節では $0^{\circ}$ 方向の載荷に限定して, 局部座屈のみが生じる場合 の MS モデルの解析精度を確認した。本節では， $45^{\circ}$ 方向の載荷や 局部座屈だけではなく溶接止端部の延性亀裂や破断が生じる場合に ついて, MS モデルの解析精度を確認する.

実験は，片持ち形式の冷間プレス成形角形鋼管柱に軸力と曲げを 与えたもので, 文献 22) に詳述している. MS モデルでは, 文献 22) に示寸平板部と角部の引張試験結果に基づく降伏応力 $\sigma_{y}$ と引張強さ $\sigma_{u}$ を与える. また, 図 15 に示す引張側骨格曲線における劣化開始

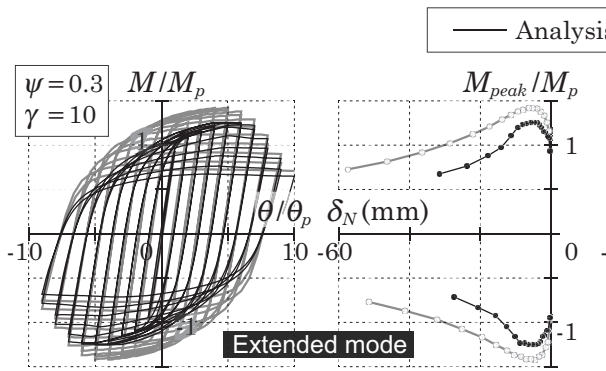

(a) $D / t=16.7, L / D=4, \quad n=0.2$

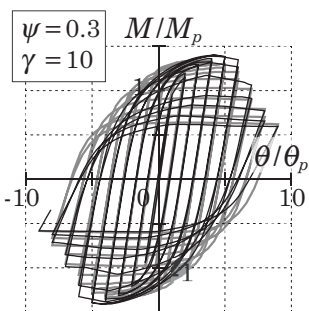

(d) $D / t=22.2, \quad L / D=2, \quad n=0.2$

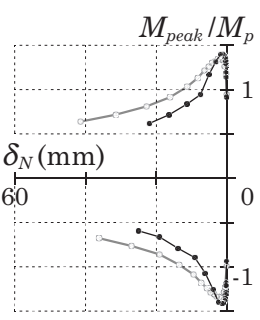

Fig. 21 Cor

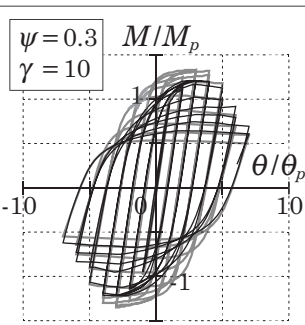

(b) $D / t=22.2, \quad L / D=4, \quad n=0.2$
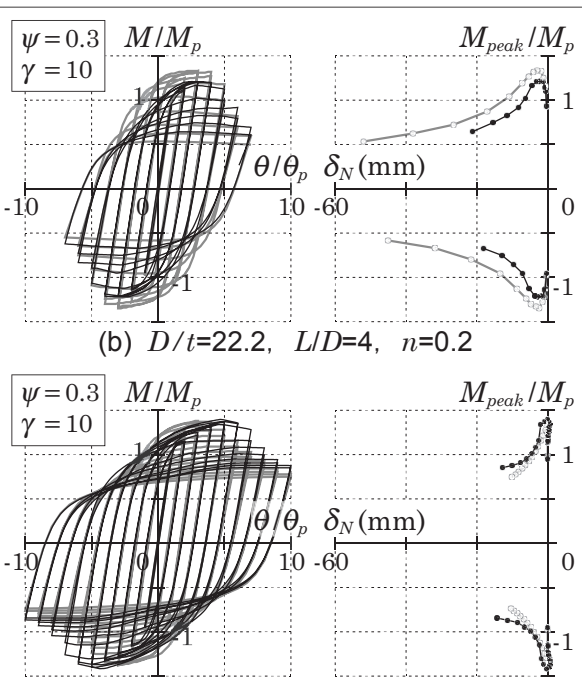

(e) $D / t=22.2, \quad L / D=4, \quad n=0.0$

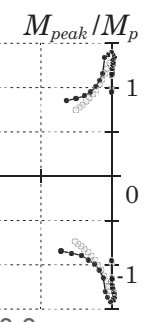

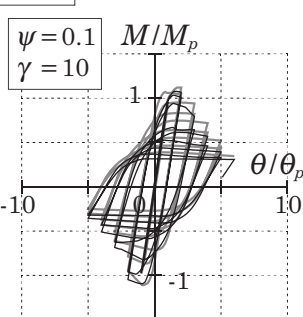

(c) $D / t=33.3, \quad L / D=4, \quad n=0.2$

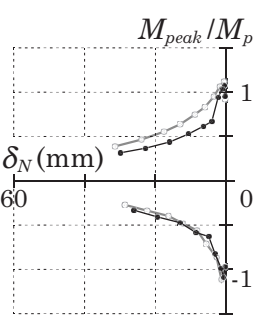

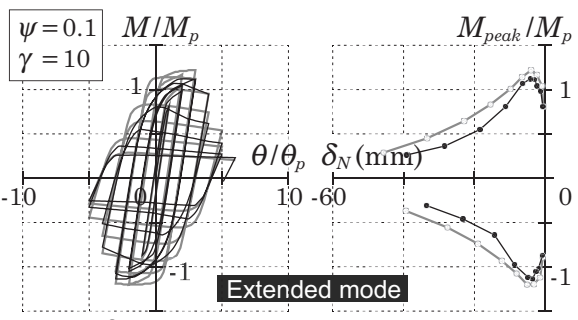

(f) $D / t=22.2, \quad L / D=4, \quad n=0.4$

sults by FEM

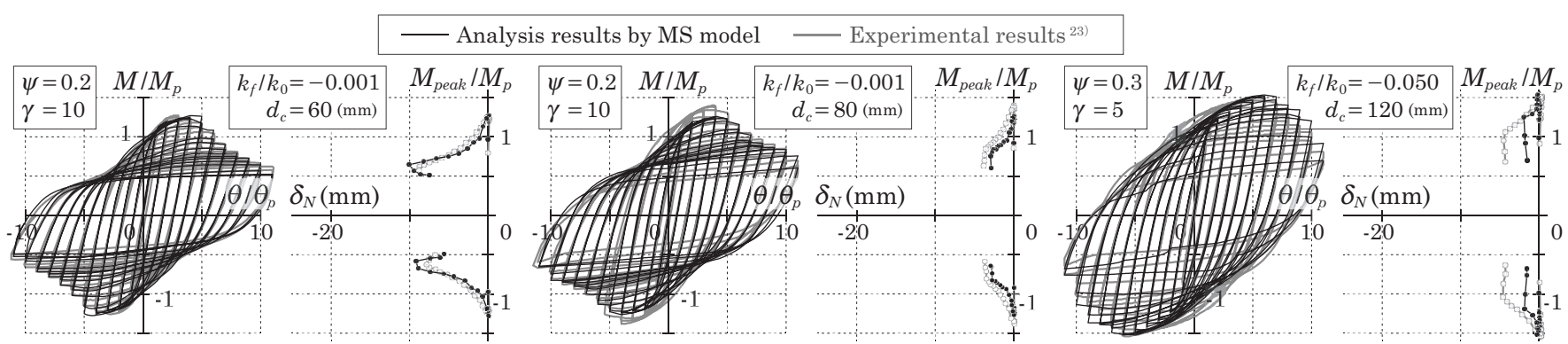

$\begin{array}{llll}\text { (a) } D / t=33.3, L / D=2.4,0 \text { degrees input, } n=0 & \text { (b) } D / t=33.3, L / D=2.4,45 \text { degrees input, } n=0 & \text { (c) } D / t=22.2, L / D=4.9,45 \text { degrees input, } n=0\end{array}$

Fig. 22 Comparsion between analysis results by MS model and experiment results 
点を定める $d_{c}$ と耐力劣化域の接線剛性 $k_{f}$, ならびに骨格曲線のシフ 卜量を定める係数 $\psi$ と RO 曲線の曲率を定める係数 $\gamma$ については, 解析と実験の対応をみながら試行錯誤的に与えている。載荷履歴は 図 20 と同じである。

\section{(2) 比較・考察}

図 22 に, $M / M_{p}$-変形角 $\theta / \theta_{p}$ 関係ならびに $M_{p e a k} / M_{p}-\delta_{N}$ 関係を, 実験と MS モデルによる解析で比較して示寸。図中には，MS モデ ルの解析で用いた $\psi$ と $\gamma$ のほかに $d_{c}$ と $k_{f}$ を示している.

図 22 の (a) と (b) は, 最終サイクルを除いて局部座屈が顕著に生

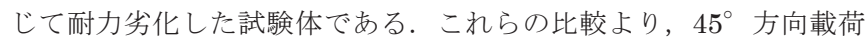
でMS モデルによる耐力が実験による耐力を下まわる傾向が見られ るが，耐力劣化域の挙動は解析と実験で良く対応している.

また, 図 22 の (b) と (c) は, いずれも $45^{\circ}$ 方向載荷の試験体であ るが, (c) では変形角 $\theta$ が $10 \theta_{p}$ 以降で, 延性亀裂の進展や破断によっ て耐力が急激に低下している。延性亀裂の進展や破断による耐力劣 化挙動の追跡精度は $d_{c}$ と $k_{f}$ の設定值に依存し, 本論ではこれらの值 を文献 18) と同様，試行錯誤的に与えているものの，4.2 節で説明し た引張側骨格曲線のモデル化によって亀裂発生後の耐力劣化を概放 精度良く再現できている．なお， $d_{c}$ と $k_{f}$ の設定方法については今後 の課題と考えている.

\section{6. 結論}

本論では，冷間プレス成形角形鋼管柱を対象とし，局部座屈によ る耐力劣化挙動を精度よく追跡できる解析モデルとして, マルチス プリングモデル (MS モデル)の構築方法を提案した．MS モデルにお ける軸ばねの軸力一軸方向変形関係の構築に際して，本論で新たに考 慮した点は以下のとおりである。

・角形鋼管の平板部と角部における材料特性の差異 (3 章).

・局部座屈発生後の軸ばねの履歴特性 $(4.3$ 節 $(3))$.

・軸ばねの長さによらない軸力ー軸方向変形関係の定式化（4.3 節 (2) $・(3))$.

軸力と曲げモーメントを受ける角形鋼管柱の耐力劣化挙動の追跡 精度を確認するために, 提案した MS モデルを有限要素法解析また は既往の載荷実験 ${ }^{22)}$ と比較した。その結果，伸張モードが生じる場 合に MS モデルの耐力と軸方向変形が小さく評価されることを除い て, 検討したパラメータの範囲内で概ね良好な解析精度が得られる ことを確認した

Table A1 Material properties

\begin{tabular}{|c|c|c|c|c|c|}
\hline Part & $\sigma_{y}\left(\mathrm{~N} / \mathrm{mm}^{2}\right)$ & $\sigma_{u}\left(\mathrm{~N} / \mathrm{mm}^{2}\right)$ & $\varepsilon_{u}(\%)$ & $a$ & $b$ \\
\hline Flat area & 357.5 & 550 & 20 & 1.0 & 11 \\
\hline Corner area & 480 & 600 & 8 & 0.3 & 22 \\
\hline Weld area & 500 & 650 & 15 & 0.3 & 21 \\
\hline
\end{tabular}

ただし，本論では図 A1 に示す 1 種類の応力一歪関係を有するプレ ス成形角形鋼管に限定して検討しているため，同じ材料強度でも応 力一歪関係の概形や硬化特性が異なる場合，材料強度が異なる場合， さらにはロール成形角形鋼管など角部の曲率半径が異なる場合への 適用性についても，今後検討が必要と考えられる.

\section{付録 1 有限要素法解析に適用した鋼材の応力-歪関係}

文献 22)では, $490 \mathrm{~N} / \mathrm{mm}^{2}$ 級の冷間プレス成形角形鋼管の平板部・角部なら びに鋼管端の完全溶込み溶接部から採取した丸鋼試験片の引張試験を行ってい る. 本論では文献 22) の結果を参考にして, 平板部・角部・溶接部の降伏応力 $\sigma_{y}$ ·引張強さ $\sigma_{u}$. 一様伸び $\varepsilon_{u}$ を表 $\mathrm{A} 1$ のように定め, これを概衩再現できる ように次式の Ramberg-Osgood 曲線で $\sigma-\varepsilon$ 関係を近似している.

$$
\frac{\varepsilon}{\varepsilon_{y}}=\frac{\sigma}{\sigma_{y}}+a\left(\frac{\sigma}{\sigma_{y}}\right)^{b}
$$

ここで， $\varepsilon_{y}$ は降伏歪 $\left(=\sigma_{y} / E, \quad\left(E=205000 \mathrm{~N} / \mathrm{mm}^{2}\right)\right)$ で， $a ， b$ は表 $\mathrm{A} 1$ に示す 值を個別に与えている.

3 章, 5 章の有限要素法解析では, (A1) 式の $\sigma-\varepsilon$ 関係を図 $\mathrm{A} 1$ に示す真応 力-真塑性歪関係に変換して用いる。 なお，実際の泠間プレス成形角形鋼管の 角部では, 角部頂点から平板部にわたって，ならびに板厚の外側から内側にわ たって，機械的性質が連続的に変化するものと考えられるが，本論では角部頂 点の板厚中心で採取した $\sigma-\varepsilon$ 関係を角部の全要素に一様に与えている.

\section{付録 2 有限要素法解析モデルの妥当性検証}

5.1 節で説明した有限要素法解析モデルの妥当性を確認するため, 片持ち形 式の冷間プレス成形角形鋼管柱に軸力と曲げを与えた既往の繰返し載荷実験 22 と有限要素法解析を比較する. 図 $\mathrm{A} 2$ に幅厚比 $D / t$ と軸力比 $n$ が異なる 2 種類 の試験体について, $M / M_{p}-\theta / \theta_{p}$ 関係ならびに $M_{\text {peak }} / M_{p}-\delta_{N}$ 関係を示す.

図 A2 より, いずれの場合も実験と解析との差異は極めて小さく, 5.1 節の 有限要素法解析モデルは妥当であることがわかる．なお，ここで示した 2 種類 の試験体以外についても，延性亀裂・破断が支配的でない場合は，実験と解析 が良い対応を示していることを確認している。

\section{参考文献}

1) Architectural Institute of Japan: Report on the Hanshin-Awaji earthquake disaster, Building series volume 3, 1997.10 日本建築学会：阪神・淡路大震災調査報告, 建築編 $-3,1997.10$

2) Architectural Institute of Japan: Report on damage investigation of the 2016 Kumamoto earthquake, 2018.6

日本建築学会 : 2016 年熊本地震災害調査報告, 2018.6

3) Y. Shimada, et al.: Collapse behavior on shaking table test, -Dynamic collapse test of full-scale 4 story steel building Part 3-, Journal of Structural and Construction Engineering (Transactions of AIJ), Vol.75, No.653, pp.1351-1360, 2010.7

島田侑子，吹田啓一郎，山田哲，松岡祐一，多田元英，大崎純，笠井和彦： 震動台実験における倒壊挙動, 実大 4 層鉄骨造建物の完全崩壊実験その 3 , 日本建築学会構造系論文集, 第 75 巻, 第 653 号, pp.1351-1360, 2010.7

4) J. Kubota, et al.: Collapse behavior of 18-story steel moment frame on shaking table test under long period ground motion, Journal of Structural and Construction Engineering (Transactions of AIJ), Vol.83, No.746, pp.625-635, 2018.4

久保田淳，高橋元美，澤本佳和，鈴木芳隆，聲高裕治，伊山潤，長江拓也：

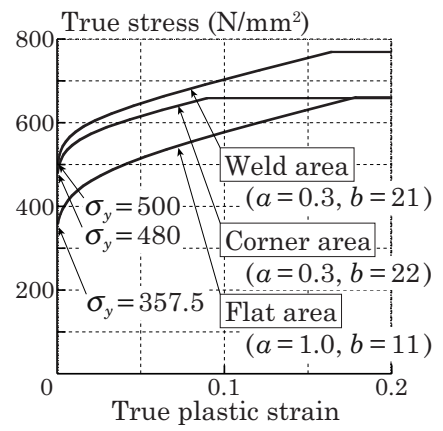

Fig. A1 Material properties for FEM

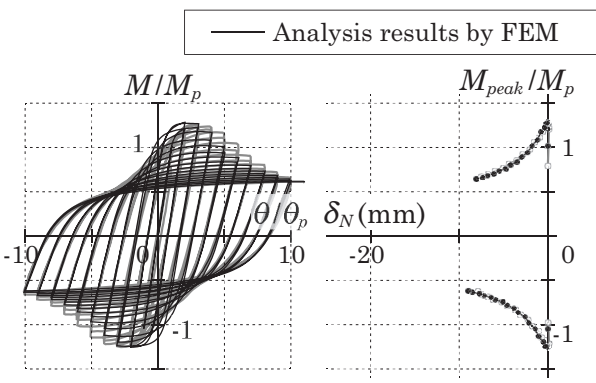

(a) $D / t=33.3, L / D=2.4,0$ degrees input, $n=0$

Fig. A2 Comparsion between FEA result and experimental result 
鉄骨造 18 層骨組を対象とした振動台実験における長周期地震動による骨 組崩壊挙動, 日本建築学会構造系論文集, 第 83 巻, 第 746 号, pp.625$635,2018.4$

5) M. Kurara, et al.: Effects of local buckling on deformation capacity of steel box columns subjected cyclic loading, Journal of Structural and Construction Engineering (Transactions of AIJ), No.613, pp.155-161, 2007.3

倉田真宏，金尾伊織，劉大偉，中島正愛 : 繰返し載荷を受ける角形鋼柱の 変形能力に及ぼす局部座屈の影響, 日本建築学会構造系論文集, 第 613 号, pp.155-161, 2007.3

6) T. Ine, et al.: Dynamic finite element analysis steel square pipe structure with local buckling under cyclic bending, Kyoshu branch research report of AIJ, Vol.47, pp.517-520, 2008.3

井根達比古, 弓削康平, 高山吏, 橋本裕太, 吉田典充, 梶原浩一：局部座 屈を考慮した角形鋼管柱の繰り返し曲げ挙動の有限要素解析 (その 1) 軸力 を受ける単一柱材の繰り返し曲げ挙動, 日本建築学会九州支部研究報告, 構造系, 第 47 号, pp.517-520, 2008.3

7) N. Oku, et al.: Finite element analysis of behavior in the range of large deformation for steel tube columns with defferent steel grades and manufacturaing prosseces, Kinki branch research report of AIJ, Vol.54, pp.469-472, 2014.6

奥伸之, 向出静司，松尾克也，多田元英 : 鋼種や製造工程の異なる角形鋼 管柱の大変形域挙動に関する有限要素解析, 日本建築学会近畿支部研究報 告集, 第 54 号・構造系, pp.469-472, 2014.6

8) T. Saito, et al.: Analytical research on effects of local buckling and ductile fracture on detorioating seismic respomonses of RHS columns, Kanto branch research report of AIJ, Vol.84, pp.545-548, 2014.2 齋藤剛寛，小山毅，桑村仁：地震動を受ける角形鋼管の耐力劣化に対する 局部座屈と延性破壊の影響に関する解析, 日本建築学会関東支部研究報告 集, 第 84 巻, pp.545-548, 2014.2

9) S. Yamada, et al.: Post - buckling and deteriorating behavior of box-section steel members, Journal of Structural and Construction Engineering (Transactions of AIJ), No.444, pp.135-143, 1993.2 山田哲, 秋山宏, 桑村仁 : 局部座屈を伴う箱形断面鋼部材の劣化域を含 む終局挙動, 日本建築学会構造系論文報告集, 第 444 号, pp.135-143, 1993.2

10) Y. Suzuki, D.G. Lignos: Collapse behavior of steel columns as part of steel frame buildings: experiments and numerical models, 16WCEE, Paper No.1032, 2017.1

11) N. Yasui: Elasto-plastic analysis for local buckling behavior of boxsection columns, Summaries of Technical Papers of Annual Meeting, Architectural Institute of Japan, C-1, pp.645-646, 2007.7 安井信行 : 箱形断面柱の局部座屈挙動解析, 日本建築学会大会学術講演梗 概集， C-1，pp.645-646，2007.7

12) T. Ishida, et al.: Analytical model of rhs columns under random bidirectional horizontal forces, Journal of Structural and Construction Engineering (Transactions of AIJ), Vol.78, No.691, pp.1631-1640, 2013.9

石田孝徳，山田哲，島田侑子：一定軸力下で水平 2 方向外力を受ける角形 鋼管柱の解析モデル, 日本建築学会構造系論文集, 第 78 巻, 第 691 号, pp.1631-1640, 2013.9

13) T. Ishida, et al.: Simulation of hysteretic behavior of rhs columns under bi-directional horizontal forces and variable axial force, Journal of Structural and Construction Engineering (Transactions of AIJ), Vol.79, No.699, pp.641-650, 2014.5

石田孝徳, 山田哲, 島田侑子 : 変動軸力下で水平 2 方向外力を受ける角形 鋼管柱の履歷挙動の追跡, 日本建築学会構造系論文集, 第 79 巻, 第 699 号, pp.641-650, 2014.5

14) C. Matsui, et al.: Post local buckling behavior of RHS columns, Kyushu branch research report of AIJ, Vol.25, pp.209-212, 1980.2

松井千秋, 森野捷輔, 津田惠吾, 立川博英 : 角形鋼管柱の局部座屈後挙 動について, 日本建築学会九州支部研究報告, 第 25 号, pp.209-212, 1980.2

15) K. Miyabayashi, et al.: Elasto-plastic analytical program with generalized plastic hinge in consideration of local buckling under biaxial bending moments and axial force for steel square tube, Steel Construction Engineering, JSSC, Vol.24, No.96, pp.31-43, 2017.12
宮林航希, 多田元英, 佐熊海, 向出静司 : 軸力と 2 軸曲げを受けて局部座 屈する角形鋼管柱の一般化塑性ヒンジ法による弾塑性解析プログラム, 日 本鋼構造協会鋼構造論文集, 第 24 巻, 第 96 号, pp.31-43, 2017.12

16) B. Kato, et al.: Deformation characteristics of box-shaped steel members influenced by local buckling, Transactions of the Architectural Institute of Japan, No.268, pp.71-76, 1978.6

加藤勉, 秋山宏, 北沢進 : 局部座屈を伴う箱形断面部材の変形, 日本建築 学会論文報告集, 第 268 号, pp.71-76, 1978.6

17) I. Chan, et al.: Effects of input direction of ground motion and column overdesign factor on seismic response of $3 \mathrm{D}$ steel moment frames with square tube columns, Journal of Structural and Construction Engineering (Transactions of AIJ), Vol.80, No.717, pp.1773-1783, 2015.11

陳逸鴻，聲高裕治，吹田啓一郎：角形鋼管柱を有する鋼構造立体骨組の地 震応答に及ぼす入力方向と柱梁耐力比の影響, 日本建築学会構造系論文集, 第 80 巻, 第 717 号, pp.1773-1783, 2015.11

18) K. Taniguchi, et al.: Elasto-plastic analytical model of square steel tube columns considering local buckling and fracture, Proceedings of Constructional Steel, JSSC, Vol.23, pp.430-437, 2015.11

谷口耕一, 陳逸鴻，聲高裕治，吹田啓一郎：角形鋼管柱の局部座屈および 破断を考慮した弾塑性解析モデル, 日本鋼構造協会鋼構造年次論文報告集, 第 23 巻, pp.430-437, 2015.11

19) H. Kuwamura: Mechanical properties of cold-formed steel square pipes in building structures, Steel Construction Engineering, JSSC, Vol.1, No.3, pp.171-185, 1994.9

桑村仁: 建築構造性能から見た冷間成形角形鋼管の材料特性, 日本鋼構造 協会鋼構造論文集，第 1 巻，第 3 号, pp.171-185, 1994.9

20) B. Kato, H. Akiyama: The ultimate strength of the steel beam-column (Part 4), Transactions of the Architectural Institute of Japan, No.151, pp.15-20, 1968.9

加藤勉, 秋山宏 : 鋼構造部材の耐力 (その 4), 日本建築学会論文報告集, 第 151 号, pp.15-20, 1968.9

21) L. Meng, et al.: A simplified model of steel structural members with strength deterioration used for earthguake response analysis, Journal of Structural and Construction Engineering (Transactions of AIJ), No.437, pp.115-124, 1992.7

孟令樺, 大井謙一, 高梨晃一: 鉄骨骨組地震応答解析のための耐力劣化を伴 う簡易部材モデル, 日本建築学会構造系論文報告集, 第 437 号, pp.115$124,1992.7$

22) R. Kuwada, et al.: Plastic deformation capacity of cold press-formed SHS columns determined local buckling and fracture, Journal of Structural and Construction Engineering (Transactions of AIJ), Vol.80, No.718, pp.1961-1970, 2015.12

桑田涼平, 聲高裕治, 吹田啓一郎：曲部座屈と破断をともなう冷間プレス 成形角形鋼管柱の塑性変形能力, 日本建築学会構造系論文集, 第 80 巻, 第 718 号, pp.1961-1970, 2015.12

23) K. Sato, K. Ikarashi: Effect of initial imperfection on large deformation behavior of cold-formed square steel tube member, Journal of structural engineering, Vol.60B, pp.327-337, 2014.3

佐藤公亮, 五十嵐規矩夫 : 初期不整が冷間成形角形鋼管部材の大変形挙動 に与える影響, 構造工学論文集, Vol.60B, pp.327-334, 2014.3

24) Y. Ichitsubo, S. Kuwahara: The effect of residual stress of cold-formed rectangular hollow section columns for the local buckling strength -FEM analysis for stub column tests-, Kinki branch research report of AIJ, Vol.54, pp.473-476, 2014.6

市坪佑梨, 桑原進 : 冷間成形角形鋼管の残留応力が局部座屈耐力に及ぼす 影響〜短柱圧縮材の FEM 解析による検討〜, 日本建築学会近畿支部研究 報告, 第 54 号・構造系, pp.473-476, 2014.6

25) S. Mukaide, et al.: Loading test in the range of large deformation for rhs columns with different manufacturing processes, Steel Construction Engineering, JSSC, Vol.23, No.90, pp.51-64, 2016.6 向出静司, 奥伸之, 松尾克也, 多田元英: 製造方法が異なる箱形断面柱 の大変形載荷実験, 日本鋼構造協会鋼構造論文集, 第 23 巻, 第 90 号, pp.51-64, 2016.6

26) Kozo System: Technical manual for SNAP ver.6, 5.1.12, 2012.2 構造システム : 任意形状立体フレームの弾塑性解析 SNAP ver.6 テクニ カルマニュアル，5.1.12，2012.2 


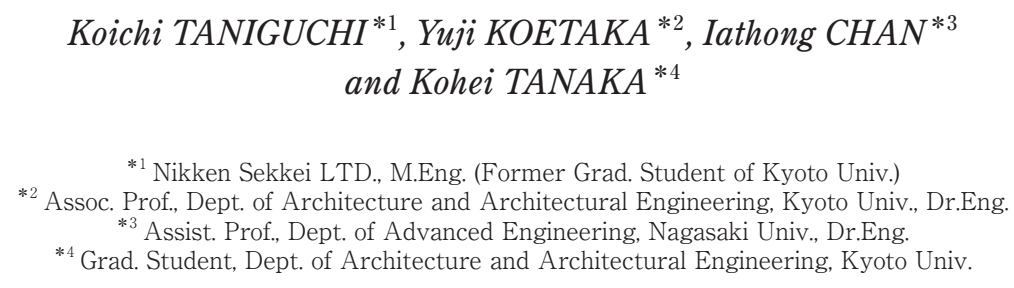

\section{Introduction}

Under quite strong ground motion, complete collapse of steel moment frames may occur because of strength deterioration by fracture and/or buckling of steel members. To simulate deterioration behavior of square hollow section (SHS) columns, which are most used in Japan, is the most important for revealing complete collapse behavior of steel moment frames. In relevant studies, multi-spring model (MS model) is often adopted for complete collapse analysis because it can achieve high accuracy result at low computational cost. In this paper, procedure to build up MS-model for cold press-formed SHS, which has not been dealt in past researches, is proposed.

\section{Outline of multi-spring model}

MS model consists of an elastic bar element and multi-spring elements, as shown in Fig. 1. The multi-spring element is a component of some uniaxial springs inserted between two rigid plates. Force-deformation relationship of the uniaxial spring is modeled in consideration of following regulations;

1) Some differences of material properties between flat area and corner area of SHS exist.

2) On hysteresis curves after local buckling occurring, stiffness during unloading becomes smaller than elastic stiffness and slip behavior occurs.

3) Plastic deformation of uniaxial spring is transformed from longitudinal plastic strain in plastic region or local buckling region in consideration of equivalence of plastic dissipation energy.

\section{Formularization of stress-strain relationships of stub-columns under axial force}

In order to clarify stress-strain relationships after local buckling of stub columns occurring, finite element method (FEM) analysis of stub columns is conducted under only axial force. Analysis parameters are width-to-thickness ratio, length-to-width ratio and cyclic loading protocols. Based on observation regarding stress-strain relationships under monotonic compression axial force and under cyclic axial force, several parameters to define approximated stress-strain relationships, as shown in Fig. 7 and 11, are formulated.

\section{Transformation for force-deformation relationships of uniaxial springs of MS model}

In order to transform for force-deformation relationships of uniaxial springs from stress-strain relationships as represented in Chapter 3, the following configurations should be considered.

1) Longitudinal strength at the end of column is larger than the strength under uniaxial stress because of constraint of circumstance strain of the column due to weld.

2) Strength of uniaxial spring of MS model is amplified from the defined stress at local buckling region, based on bending moment distribution.

3) Plastic deformation of uniaxial spring of MS model is obtained as to correspond plastic dissipation energy in the entire either plastic region or local buckling region with that of MS model.

\section{5 . Verification of validity of proposed MS model}

In order to confirm accuracy of the proposed MS model, analysis results by MS model are compared with analysis results by FEM or test results in the past research. Most of results by MS model agree well with FEM results and test results, unless width-to-thickness ratio is small.

\section{Conclusions}

As a result, it is clarified that the proposed MS-model is valid for simulating deterioration behavior of cold pressformed SHS column due to local buckling. In the further study, MS-model should be modified to adapt for other kind of SHS columns. 